\title{
QUARTERLY OUTLOOK ON MONETARY, BANKING, AND PAYMENT SYSTEM IN INDONESIA: QUARTER I, 2015
}

\author{
TM. Arief Machmud, Syachman Perdymer, Muslimin Anwar, \\ Nurkholisoh Ibnu Aman, Tri Kurnia Ayu K, Anggita Cinditya Mutiara K, \\ Illinia Ayudhia Riyadi ${ }^{1}$
}

\begin{abstract}
The economic growth slowed down during the first quarter of 2015, although the macroeconomic and the financial system stability are well maintained. Internally, the lower government consumption and investment on construction are the reasons for this economic contraction, while the external factor is the low export performance. On the other hand, the current account performed better with a lower deficit, while the inflation and the rate of Rupiah were well maintained. In the next quarter, we expect to gain support from domestic consumption and investment in 2015QII, as well as an increase of the loan disbursement by the bank.
\end{abstract}

Keywords: macroeconomy, monetary, economic outlook.

JEL Classification: C53, E66, F01, F41

1 Authors are researcher on Monetary and Economic Policy Department (DKEM). TM_Arief Machmud (tm_arief@bi.go.id); Syachman Perdymer (syachman@bi.go.id); Muslimin AAnwar (imus@bi.go.id); Nurkholisoh Ibnu Aman (nurkholisoh@bi.go.id); Tri Kurnia Ayu K (tri_kas@bi.go.id); Anggita Cinditya Mutiara K (anggita_cmk@bi.go.id); Illinia Ayudhia Riyadi (illinia_ar@bi.go.id). 


\section{PERKEMBANGAN GLOBAL}

Pemulihan ekonomi global masih berjalan tidak seimbang dengan risiko di pasar keuangan global yang masih tinggi. Pertumbuhan ekonomi diperkirakan tidak secepat perkiraan semula seiring lebih rendahnya prakiraan pertumbuhan ekonomi AS dan Tiongkok. Prakiraan ekonomi AS tersebut didorong oleh melambatnya kegiatan produksi, terutama akibat menurunnya permintaan eksternal sejalan dengan penguatan dolar AS terhadap mata uang dunia. Perkembangan ini telah mendorong berlanjutnya ketidakpastian waktu dan besarnya kenaikan suku bunga Fed Fund Rate (FFR) di AS dan tekanan pembalikan modal portofolio dari emerging markets. Perlambatan ekonomi juga dialami Tiongkok yang ditandai oleh terus melemahnya sektor perumahan dan sektor produksi manufaktur, walaupun berbagai kebijakan pelonggaran telah dilakukan untuk menahan perlambatan ekonomi. Sebaliknya, perekonomian Eropa diperkirakan terus membaik ditopang pelonggaran kondisi moneter dan keuangan serta dampak penurunan harga minyak. Perekonomian dunia yang melambat berdampak pada harga komoditas internasional yang masih terus menurun, meskipun harga minyak dunia mulai kembali mengalami kenaikan.

Perekonomian AS diperkirakan tumbuh lebih rendah dari prakiraan semula. Prakiraan ekonomi AS tersebut didorong oleh melambatnya kegiatan produksi, terutama akibat menurunnya permintaan eksternal sejalan dengan penguatan dolar AS terhadap mata uang dunia, yang berdampak pada penurunan ekspor. Selain itu, cuaca dingin yang menghambat rantai nilai produksi juga turut memperlambat kegiatan produksi di AS. Hal ini tercermin dari menurunnya indeks produksi dan kapasitas utilisasi (Grafik 1). Di sisi lain, peningkatan expenditure tidak setinggi peningkatan disposable income. Hal tersebut mencerminkan dampak penurunan harga minyak terhadap peningkatan konsumsi yang tidak sekuat prakiraan semula. Perkembangan kondisi ekonomi AS ini telah mendorong berlanjutnya ketidakpastian waktu dan besarnya kenaikan suku bunga Fed Fund Rate (FFR) di AS.

Perekonomian Eropa diperkirakan terus membaik. Perbaikan tersebut ditopang oleh pelonggaran kondisi moneter dan keuangan yang berdampak pada lebih rendahnya suku bunga dan penyaluran kredit yang lebih mudah. Selain itu, penurunan harga minyak berdampak pada meningkatnya permintaan domestik. Hal ini tercermin dari tingkat keyakinan konsumen dan penjualan eceran yang terus meningkat. Permintaan eksternal juga meningkat seiring dengan meningkatnya daya saing ekspor sebagai dampak positif depresiasi Euro. Peningkatan permintaan berdampak pada meningkatnya kegiatan produksi Eropa, tercermin dari tren perbaikan PMI komposit (Grafik 2). Perkembangan ini juga berdampak positif terhadap kondisi tenaga kerja dan pertumbuhan ekonomi Eropa.

Perekonomian Jepang tumbuh sesuai dengan prakiraan semula. Kinerja beberapa indikator perekonomian Jepang cenderung bervariasi. Penjualan durables goods meningkat dan tingkat keyakinan konsumen membaik, didukung oleh ekspektasi kenaikan gaji pada negosiasi gaji tahunan (spring) dan dampak penurunan harga minyak. Sementara itu, pertumbuhan upah 


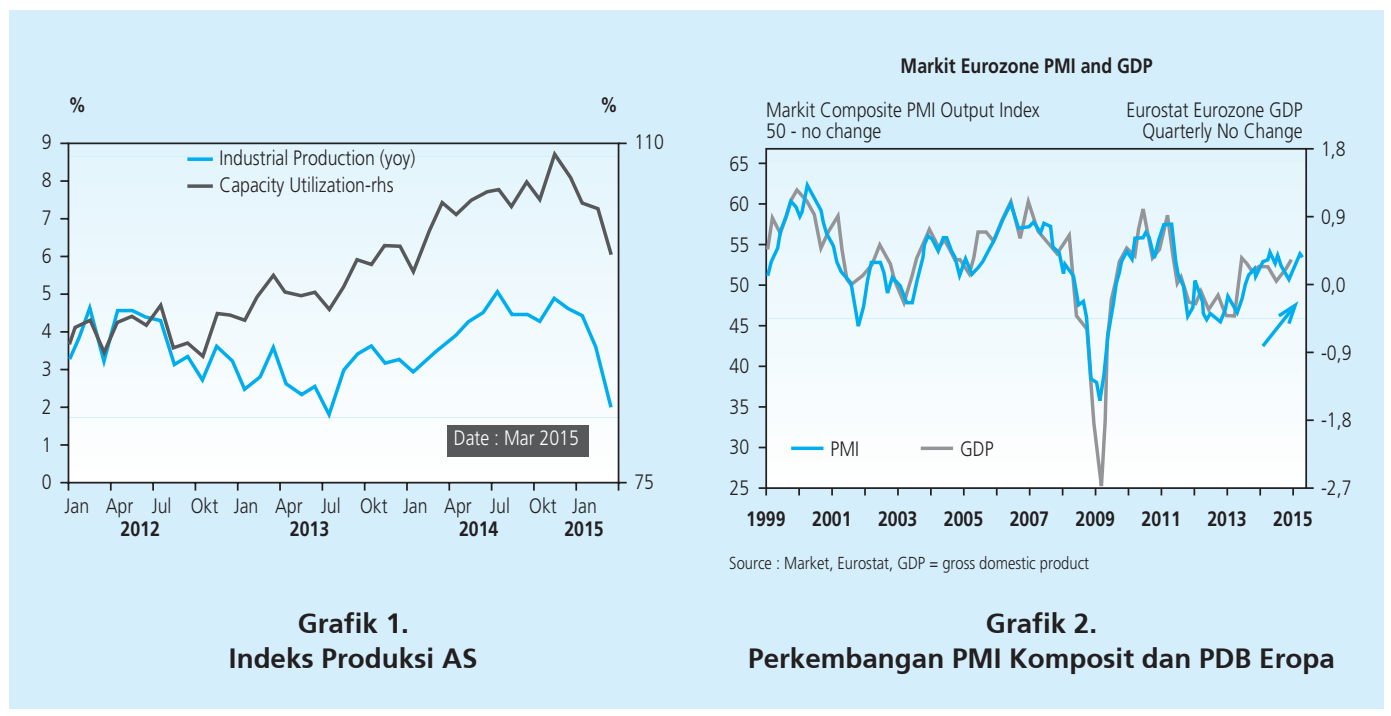

riil juga mulai membaik meskipun masih negatif. Berbeda dengan indikator di sisi permintaan yang membaik, indikator produksi belum menunjukkan tanda-tanda perbaikan, sementara indikator manufaktur PMI memasuki zona kontraktif. Untuk mendukung perekonomiannya, Bank of Japan (BOJ) diperkirakan akan menambah target quantitative easing (QE) tahunan dari 80 triliun yen menjadi 90 triliun yen.

Perekonomian Tiongkok mengalami perlambatan. Kondisi ini ditandai oleh terus melemahnya sektor perumahan yang berpengaruh pada menurunnya pertumbuhan konsumsi baja dan aktivitas konstruksi (Grafik 3). Sementara itu, sektor produksi manufaktur juga turut melemah, tercermin dari penurunan investasi aset tetap yang terjadi semakin dalam sementara indeks produksi dan PMI berada dalam tren menurun. Untuk menahan perlambatan ekonomi yang terjadi dan upaya mencapai target pertumbuhan sekitar $7 \%$, berbagai kebijakan pelonggaran telah dilakukan. Namun, dampak dari kebijakan pelonggaran tersebut masih terbatas, tercermin pada masih rendahnya pertumbuhan uang beredar dan kredit. Hal tersebut terjadi karena masih besarnya beban utang sejalan dengan leverage korporasi yang masih tinggi.

Perekonomian India diperkirakan tumbuh lebih tinggi pada tahun 2015. Perkiraan membaiknya perekonomian India terutama didukung oleh optimisme reformasi struktural dan penurunan harga minyak. Optimisme reformasi struktural oleh Pemerintah tercermin pada peningkatan tingkat keyakinan bisnis (Grafik 4). Sejalan dengan optimisme domestik, indikator produksi menunjukkan perbaikan, khususnya pada sektor batu bara, listrik, pertambangan lain dan consumer goods. Selain itu, penjualan mobil juga berada pada tren meningkat.

Perkembangan perekonomian dunia yang melambat berdampak pada harga komoditas internasional yang masih terus menurun, meskipun harga minyak dunia mulai kembali mengalami 


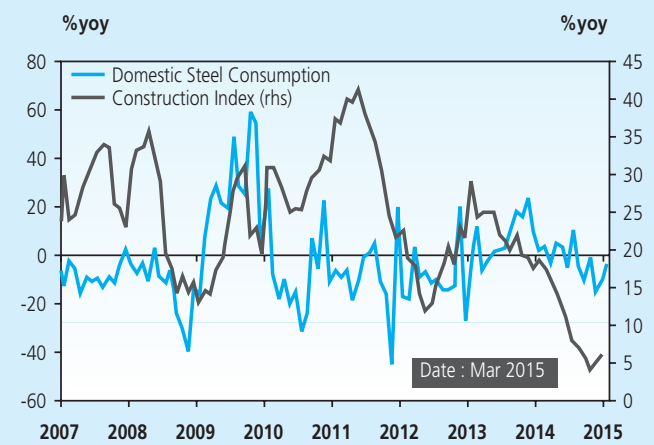

Source : CEIC, Bloomberg (calculated)

Grafik 3. Perkembangan Konsumsi Baja dan Konstruksi Tiongkok

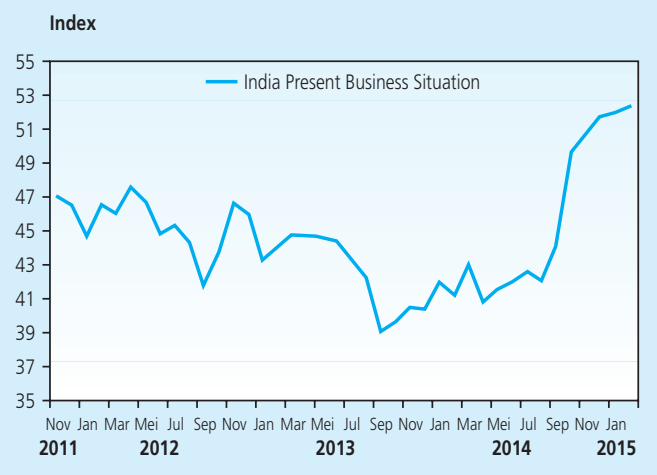

Grafik 4.

Tingkat Keyakinan Bisnis India

kenaikan. Penurunan harga terbesar terutama terjadi pada komoditas batubara dan karet seiring dengan penurunan harga minyak. Selain itu, penurunan harga batubara, tembaga, nikel, timah juga sejalan dengan pelemahan permintaan Tiongkok. Di sisi lain, harga minyak mulai kembali mengalami kenaikan. Kenaikan tersebut didorong oleh kekhawatiran gangguan keamanan di Yaman, pelemahan USD, dan melambatnya peningkatan inventory minyak AS. Tren kenaikan harga minyak juga dikonfirmasi oleh posisi net long managed money yang semakin tinggi. Meskipun demikian, tren kenaikan harga akan berlangsung lambat karena besarnya faktorfaktor yang menekan harga minyak untuk tetap berada di level rendah. Faktor tersebut meliputi kondisi over supply masih terjadi hingga akhir 2015, penundaan penyelesaian pengeboran sumur minyak di AS yang masih tinggi dan tingginya level inventory minyak dunia.

Di sisi pasar keuangan global, risiko di pasar keuangan global masih tinggi. Perkembangan kondisi perekonomian AS telah mendorong berlanjutnya ketidakpastian waktu dan besarnya kenaikan suku bunga Fed Fund Rate (FFR) di AS dan tekanan pembalikan modal portofolio dari emerging markets. Normalisasi Fed diprakirakan baru akan terjadi paling cepat September 2015, dengan peluang tertinggi di Desember 2015. Berdasarkan survei Bloomberg kepada 73 economists pada Mei 2015, sebagian besar pelaku pasar memperkirakan kenaikan FFR paling cepat pada triwulan III 2015 sebesar 25 bps. Sementara itu, Fed Fund futures menunjukkan bahwa terdapat 32\% kemungkinan FOMC akan mengumumkan suku bunga FFR sebesar 0,5\% (naik 25 bps) pada FOMC meeting Desember 2015. Di sisi lain, the Fed juga mempertimbangkan faktor stabilitas sistem keuangan dalam proses pengambilan keputusan normalisasi. 


\section{DINAMIKA MAKROEKONOMI INDONESIA}

\subsection{Pertumbuhan Ekonomi}

Di sisi domestik, pertumbuhan ekonomi pada triwulan I 2015 melambat, namun diperkirakan akan membaik pada triwulan-triwulan mendatang. Pertumbuhan pada triwulan I 2015 tercatat sebesar 4,7\% (yoy), melambat dibandingkan triwulan sebelumnya sebesar 5,0\% (yoy). Hal ini terutama didorong lemahnya kinerja beberapa komponen permintaan domestik terutama konsumsi pemerintah dan investasi pada sektor bangunan. Belum terealisirnya belanja pada beberapa kementerian dan lembaga yang baru serta masih terbatasnya belanja modal terkait dengan implementasi proyek-proyek infrastruktur pemerintah mengakibatkan lemahnya kinerja konsumsi pemerintah dan investasi bangunan. Secara spasial, perlambatan ekonomi pada triwulan I 2015 terjadi hampir merata di seluruh wilayah Indonesia, baik di wilayah Jawa dan Jakarta, yang mengandalkan sektor manufaktur, maupun wilayah Sumatera dan Kalimantan, daerah penghasil komoditas sumber daya alam.

\begin{tabular}{|c|c|c|c|c|c|c|}
\hline \multicolumn{7}{|c|}{$\begin{array}{c}\text { Tabel } 1 \\
\text { Pertumbuhan Ekonomi Sisi Pengeluaran (\%,yoy) }\end{array}$} \\
\hline \multirow{3}{*}{ Komponen } & & & & \multicolumn{3}{|c|}{ \%Y-o-Y, Tahun Dasar 2010} \\
\hline & \multicolumn{4}{|c|}{2014} & \multirow{2}{*}{2014} & \multirow{2}{*}{$\begin{array}{c}2015 \\
\text { I }\end{array}$} \\
\hline & I & II & III & IV & & \\
\hline Konsumsi Rumah Tangga & 5,7 & 5,5 & 5,1 & 4,9 & 5,3 & 4,7 \\
\hline Konsumsi Pemerintah & 6,1 & $-1,5$ & 1,3 & 2,8 & 2,0 & 2,2 \\
\hline Investasi & 5,5 & 3,7 & 3,9 & 4,3 & 4,1 & 4,4 \\
\hline Ekspor & 3,2 & 1,4 & 4,9 & $-4,5$ & 1,0 & $-0,5$ \\
\hline Impor & 5,0 & 0,4 & 0,3 & 3,2 & 2,2 & $-2,2$ \\
\hline PDB & 5,1 & 5,0 & 4,9 & 5,0 & 5,0 & 4,7 \\
\hline
\end{tabular}

Konsumsi rumah tangga pada triwulan I 2015 tumbuh melambat terutama didorong oleh melemahnya pendapatan. Melemahnya pendapatan tercermin dari perkembangan Nilai Tukar Petani (NTP), upah buruh tani riil, dan upah buruh bangunan riil yang masih terkontraksi. Perlambatan konsumsi rumah tangga tersebut tercermin pada penjualan kendaraan bermotor yang masih mencatat kontraksi pada triwulan I 2015. Selain itu, melambatnya konsumsi rumah tangga sejalan dengan menurunnya keyakinan konsumen.

Konsumsi pemerintah pada triwulan I 2015 tumbuh lebih rendah dibandingkan dengan triwulan sebelumnya disebabkan oleh realisasi belanja barang yang melambat. Konsumsi pemerintah tercatat sebesar 2,2\% (yoy), lebih rendah dibandingkan dengan triwulan IV 2014 yang tumbuh sebesar 2,8\% (yoy). Belum terealisirnya belanja pada beberapa kementerian dan lembaga yang baru mengakibatkan penyerapan belanja barang yang lebih rendah dibandingkan 
dengan pola historis triwulan I. Kondisi tersebut berdampak pada lemahnya kinerja konsumsi pemerintah.

Dari komponen investasi, pertumbuhan tercatat sedikit lebih tinggi terutama didorong oleh perbaikan kinerja investasi nonbangunan. Investasi kembali tumbuh meningkat dari 4,3 (yoy) pada triwulan IV 2014 menjadi 4,4\% (yoy) pada triwulan I 2015. Kinerja investasi tersebut didorong oleh aktivitas investasi nonbangunan yang meningkat, sementara investasi bangunan tumbuh sedikit melambat. Investasi nonbangunan pada triwulan I 2015 tumbuh lebih baik bersumber dari kinerja positif komponen mesin dan perlengkapan dengan kontraksi yang semakin menurun menjadi -0,95\% (yoy) dibandingkan dengan triwulan IV 2014 sebesar $-9,07 \%$ (yoy). Sementara itu, investasi bangunan melambat sejalan dengan indikator bangunan yang belum membaik, sebagaimana tercermin pada penjualan semen yang menurun sepanjang triwulan I 2015. Hal ini dipengaruhi oleh sikap wait and see sektor swasta dan masih belum berjalannya proyek-proyek pemerintah. Realisasi pembangunan proyek infrastruktur pemerintah yang masih terbatas terkait dengan kendala administrasi, yakni perubahan nomenklatur pada Kementerian.

Kinerja ekspor pada triwulan I 2015 masih terkontraksi, meskipun mengecil ditopang oleh membaiknya ekspor pertambangan dan pertanian. Ekspor pada triwulan I 2015 mencatat kontraksi 0,5\% (yoy), lebih kecil dibandingkan dengan triwulan sebelumnya (-4,5\%, yoy). Pertumbuhan ekspor riil yang membaik terutama didukung oleh kinerja ekspor pertambangan dan pertanian yang meningkat (Grafik 5). Ekspor pertambangan yang meningkat antara lain dipengaruhi oleh base effect terkait dengan terbatasnya ekspor mineral pada triwulan I 2014 akibat pemberlakuan kebijakan ekspor tambang mineral yang berlaku sejak bulan Januari 2014. Ekspor tambang (tembaga, nikel, bauksit) yang sempat turun tajam pada triwulan I dan II 2014, berangsur membaik sejak triwulan III 2014 seiring dengan realisasi ekspor oleh Freeport dan Newmont. Ekspor komoditas pertanian juga tumbuh positif didorong oleh ekspor kopi dan buah-buahan. Di sisi lain, ekspor manufaktur masih tumbuh melambat akibat penurunan ekspor karet olahan, produk kimia, dan alat listrik. Hal ini sejalan dengan penurunan volume dan koreksi harga.

Merespons kinerja konsumsi yang melambat dan ekspor yang masih terkontraksi, impor tumbuh negatif pada triwulan I 2015. Impor tercatat mengalami kontraksi sebesar 2,2\% (yoy), lebih rendah dibandingkan dengan triwulan sebelumnya yang tumbuh 3,2\% (yoy). Kinerja impor yang melemah terutama disumbang oleh impor barang modal yang masih terkontraksi cukup besar, sejalan dengan penjualan alat berat domestik yang masih tumbuh negatif akibat aktivitas bisnis pertambangan, sebagai pasar utama penjualan alat berat, yang belum membaik. Namun demikian, impor barang modal mulai mengalami kenaikan signifikan pada akhir triwulan I 2015 yang ditengarai sebagai langkah persiapan pelaksanaan pembangunan infrastruktur (Grafik 6). 


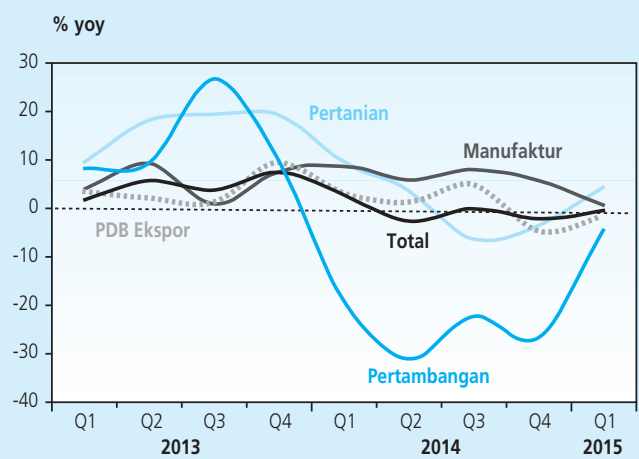

Grafik 5. Pertumbuhan Ekspor Nonmigas Riil

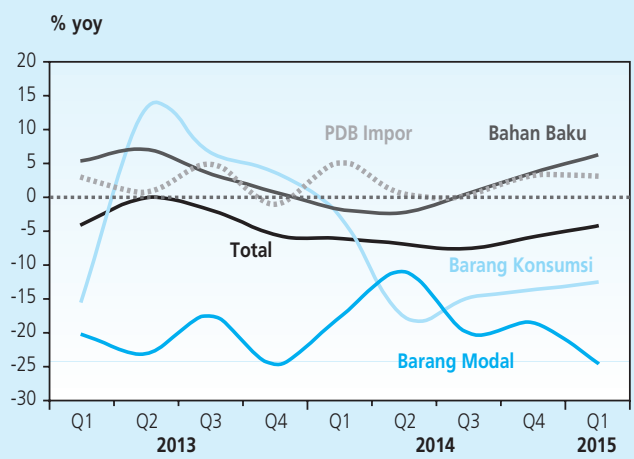

Grafik 6. Pertumbuhan Impor Nonmigas Riil

Dari sisi sektoral (lapangan usaha), perlambatan ekonomi pada triwulan I 2015 terjadi di hampir seluruh sektor ekonomi. Sektor industri pengolahan tumbuh melambat seiring dengan menurunnya permintaan ekspor dan masih lemahnya permintaan domestik. Sektor pertambangan juga menurun, bersumber dari menurunnya lifting migas dan produksi batubara. Di sisi lain, kinerja sektor pertanian, kehutanan dan perikanan membaik bersumber dari perbaikan kinerja tanaman perkebunan dan perikanan. Sementara itu, sebagian besar sektor nontradables juga tumbuh lebih rendah dari triwulan sebelumnya. Sektor bangunan tumbuh melambat disebabkan oleh masih adanya sikap wait and see sektor swasta dan masih belum berjalannya proyek-proyek pemerintah. Sektor transportasi dan pergudangan melambat sejalan dengan melambatnya aktivitas perekonomian. Sektor penyediaan akomodasi dan makan minum juga tumbuh melambat seiring masih lemahnya konsumsi domestik dan impor yg turun lebih tajam dari perkiraan semula. Selain itu, sektor keuangan, persewaan, dan jasa tumbuh melambat karena melambatnya kinerja subsektor jasa keuangan, real estate, dan jasa perusahaan. Di sisi lain, pertumbuhan sektor informasi dan komunikasi meningkat seiring diluncurkannya teknologi broadband 4G-LTE meskipun masih dalam kapasitas terbatas.

Secara spasial, perlambatan ekonomi pada triwulan I 2015 terjadi hampir merata di seluruh wilayah Indonesia, baik di wilayah Jawa dan Jakarta, yang mengandalkan sektor manufaktur, maupun wilayah Sumatera dan Kalimantan, daerah penghasil komoditas sumber daya alam (Gambar 1). Di Jawa (termasuk Jakarta), perlambatan ekonomi terutama disebabkan oleh menurunnya kinerja industri pengolahan, sejalan dengan melemahnya ekspor. Di wilayah Sumatera, penurunan kinerja pertambangan migas di Provinsi Nangroe Aceh Darusalam dan Provinsi Riau menjadi faktor utama penyebab kontraksi pertumbuhan ekonomi di kedua provinsi tersebut. Hal ini terkait dengan berhentinya produksi gas alam di Aceh, dan lifting minyak bumi yang terus turun di Riau. Sementara itu, perlambatan ekonomi nasional juga didorong oleh 
kontraksi ekonomi di Provinsi Kalimantan Timur, terkait dengan pemburukan kinerja sektor batubara, yang merupakan komoditas utama Kalimantan. Sebaliknya, perekonomian Sulampua Bali-Nusra tumbuh lebih tinggi, dibandingkan dengan triwulan sebelumnya, terkait dengan perbaikan kinerja tambang tembaga di Papua dan Nusa Tenggara Barat.

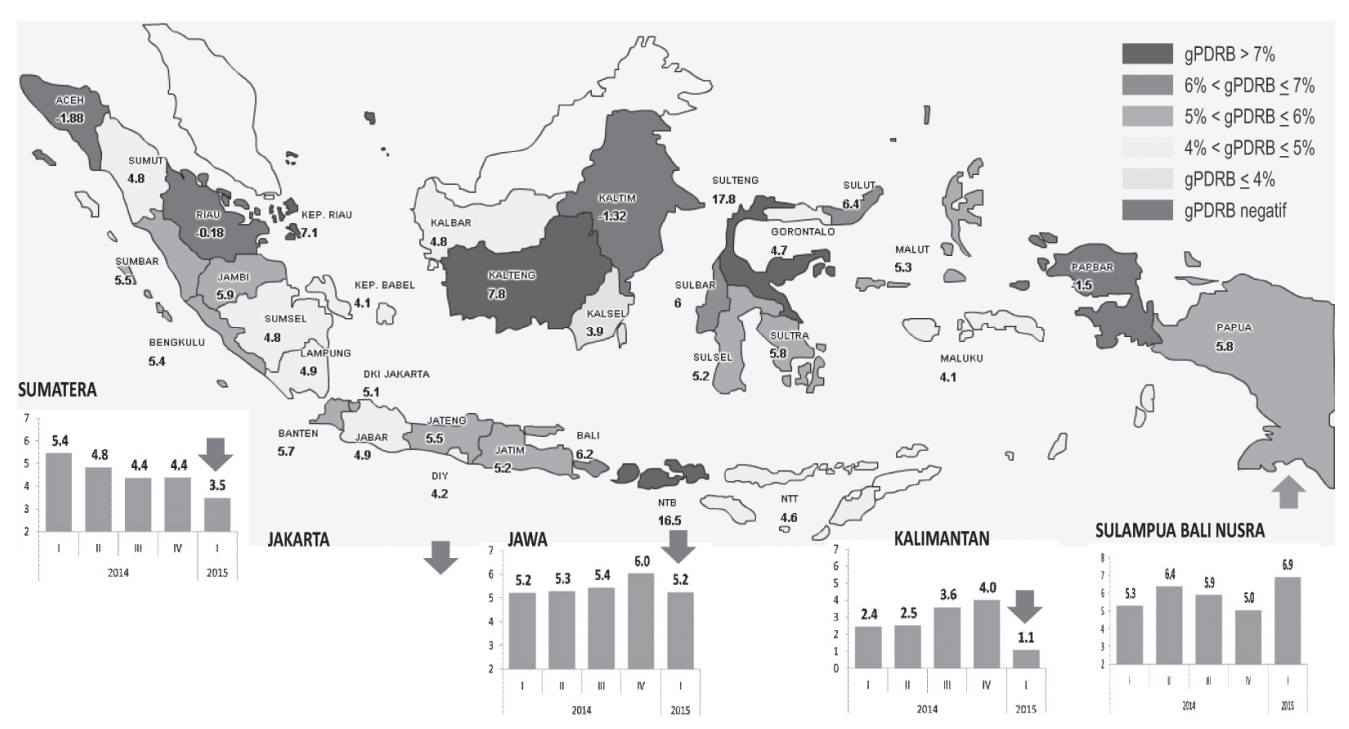

Gambar 1.

Peta Pertumbuhan Ekonomi Daerah Triwulan I 2015

\subsection{Neraca Pembayaran Indonesia}

Neraca Pembayaran Indonesia (NPI) pada triwulan I 2015 mencatat surplus, terutama ditopang oleh defisit transaksi berjalan yang menurun. Defisit transaksi berjalan triwulan I 2015 menurun, terutama didorong oleh menurunnya defisit neraca migas. Defisit transaksi berjalan tercatat sebesar 3,8 miliar dolar AS (1,8\% PDB) pada triwulan I 2015, lebih rendah dari triwulan sebelumnya sebesar 5,7 miliar dolar AS (2,6\% PDB). Defisit tersebut juga lebih rendah dari defisit pada triwulan yang sama pada 2014 sebesar 4,1 miliar dolar AS (1,9\% PDB). Peningkatan kinerja transaksi berjalan terutama ditopang oleh perbaikan neraca perdagangan migas seiring dengan menyusutnya impor minyak karena harga minyak dunia yang lebih rendah dan turunnya konsumsi bahan bakar minyak (BBM) sebagai dampak positif dari reformasi subsidi yang ditempuh Pemerintah. Di sisi nonmigas, surplus neraca perdagangan nonmigas tercatat lebih rendah akibat turunnya ekspor nonmigas (-8,0\% yoy) seiring dengan dalamnya penurunan harga komoditas, meskipun impor nonmigas juga mencatat penurunan -3,7\% (yoy) di tengah pertumbuhan ekonomi domestik yang melambat. Perbaikan kinerja transaksi berjalan juga disumbang oleh berkurangnya defisit neraca jasa mengikuti turunnya impor 
barang, berkurangnya pengeluaran wisatawan nasional selama berkunjung ke luar negeri, dan turunnya neraca pendapatan primer seiring dengan pola musimannya.

Sementara itu, di tengah meningkatnya ketidakpastian di pasar keuangan global, Transaksi Modal dan Finansial triwulan I 2015 tetap surplus. Transaksi modal dan finansial mencatat surplus pada triwulan I 2015, terutama ditopang oleh aliran masuk modal asing dalam bentuk investasi portofolio dan investasi langsung. Pada investasi portofolio, secara akumulatif aliran masuk modal portofolio asing pada triwulan I 2015 lebih besar dari inflow pada triwulan IV 2014. Derasnya inflow pada triwulan I 2015 tersebut tidak hanya bersumber dari penerbitan surat berharga global oleh Pemerintah, namun juga karena masih kuatnya pembelian investor asing terhadap surat berharga negara berdenominasi rupiah dan saham pada periode JanuariFebruari 2015. Di sisi lain, aliran masuk investasi langsung pada triwulan I 2015 tercatat sebesar 5,3 miliar dolar AS. Besarnya arus masuk investasi langsung tersebut mencerminkan kepercayaan investor terhadap kondisi fundamental ekonomi Indonesia serta prospek pertumbuhan ekonomi ke depan yang terjaga dengan baik. Namun, surplus transaksi modal dan finansial triwulan I 2015 lebih rendah dibandingkan dengan surplus triwulan sebelumnya yang mencapai 8,9 miliar dolar AS terutama karena meningkatnya penempatan simpanan sektor swasta di luar negeri dan penarikan pinjaman luar negeri swasta yang lebih rendah.

Perbaikan transaksi berjalan dan surplus transaksi modal dan finansial menyebabkan Neraca Pembayaran Indonesia (NPI) triwulan I 2015 secara keseluruhan surplus. NPI triwulan I 2015 mencatat surplus sebesar US\$1,3 miliar (Grafik 7). Dengan perkembangan tersebut, posisi cadangan devisa pada akhir Maret 2015 tercatat sebesar US\$111,6 miliar (Grafik 8). Jumlah cadangan devisa ini cukup untuk membiayai kebutuhan pembayaran impor dan utang luar negeri Pemerintah selama 6,6 bulan dan berada di atas standar kecukupan internasional.

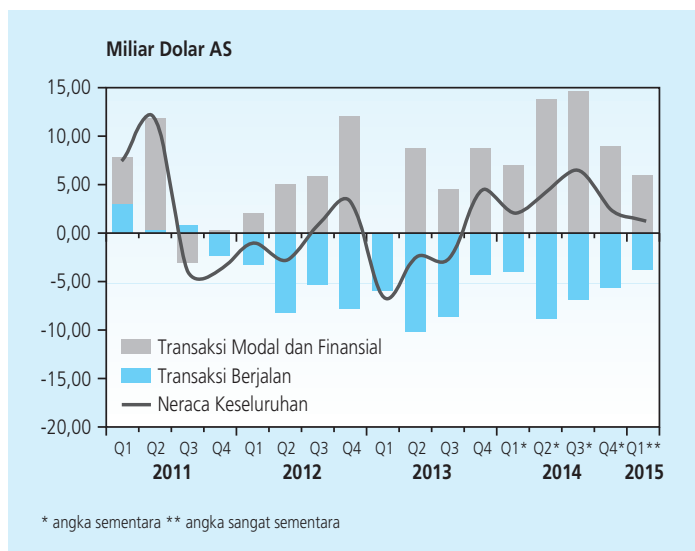

Grafik 7.

Neraca Pembayaran Indonesia

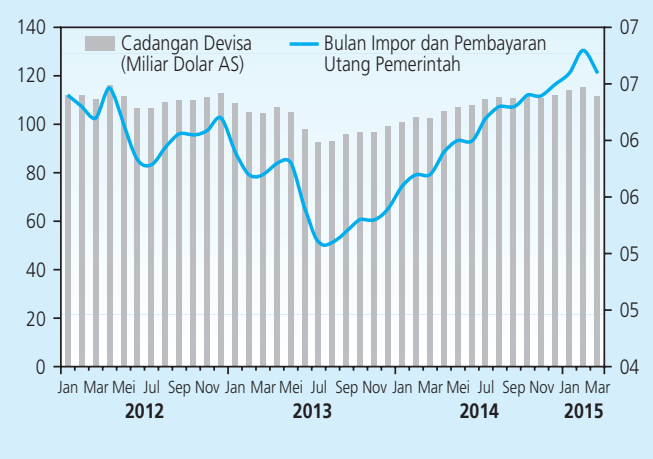

Grafik 8.

Perkembangan Cadangan Devisa 


\subsection{Nilai Tukar Rupiah}

Nilai tukar rupiah mengalami tekanan seiring penguatan dolar AS terhadap hampir semua mata uang. Pada triwulan I 2015, rupiah secara rata-rata melemah sebesar 4,4\% (qtq) ke level Rp12.807 per dolar AS. Sejalan dengan itu, secara point-to-point Rupiah terdepresiasi sebesar 5,27\% dan ditutup di level Rp.13.074 per USD (Grafik 1.9). Penguatan dolar AS yang terjadi terhadap mayoritas mata uang dunia ditopang oleh ekonomi AS yang membaik dan kebijakan Quantitative Easing ECB (Grafik 1.10).

Pada triwulan I 2015, nilai tukar mencatat peningkatan volatilitas, meskipun kembali turun pada April 2015. Peningkatan volatilitas pada triwulan I 2015 juga dialami oleh mata uang negara peers. Pada April 2015, volatilitas rupiah turun sejalan dengan upaya Bank Indonesia untuk menjaga nilai rupiah. Volatilitas rupiah pada April 2015 relatif lebih rendah dibandingkan dengan negara peers seperti Real Brasil, Lira Turki, Ringgit Malaysia, Rand Afrika Selatan, Dollar Singapura, Won Korea Selatan, dan Rupee India.

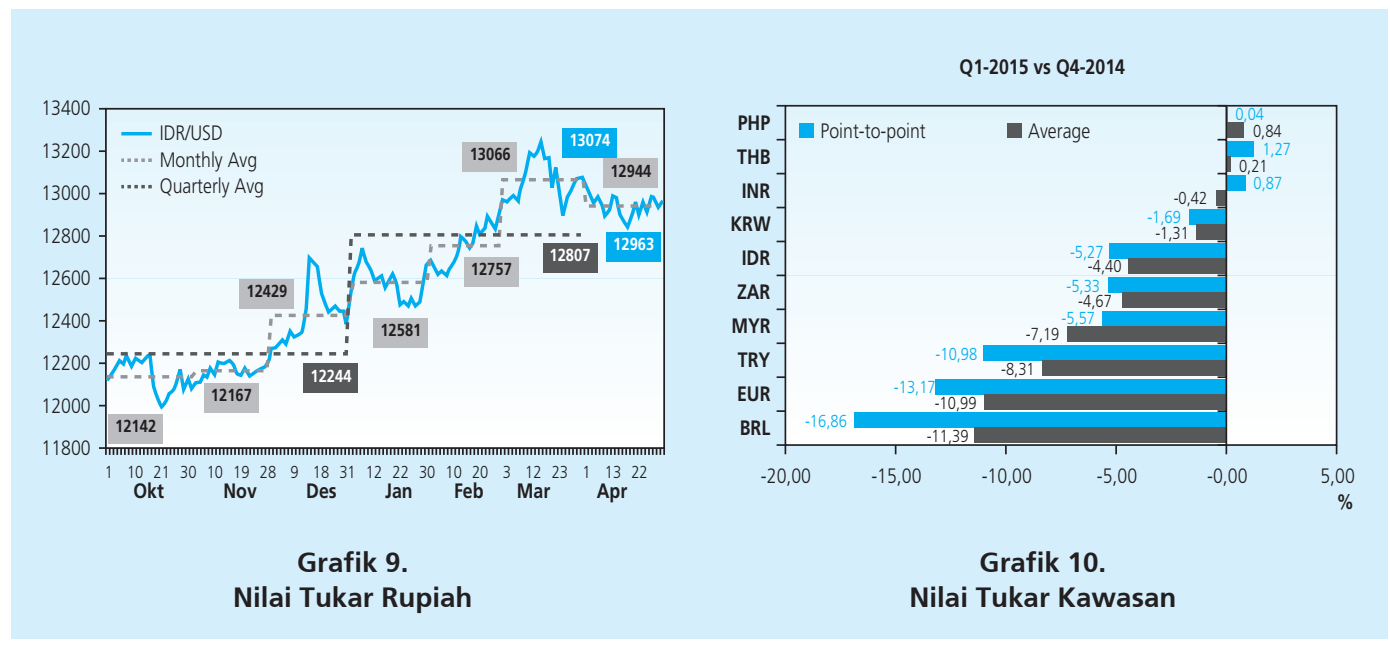

\subsection{Inflasi}

Inflasi pada triwulan I 2015 tetap terkendali dan mendukung pencapaian sasaran inflasi 2015 yakni 4,0 $1 \%$. Pada triwulan I 2015, IHK mencatat deflasi sebesar -0,44\% (qtq) atau $6,38 \%$ (yoy), menurun dibandingkan triwulan sebelumnya sebesar 4,49\% (qtq) atau 8,36\% (yoy) (Grafik 11). Penurunan ini terutama didorong oleh koreksi harga BBM pada bulan Januari dan dampak lanjutannya terhadap penurunan tarif angkutan dalam kota. Selanjutnya, koreksi harga aneka cabai juga mendorong deflasi kelompok volatile food di bulan Februari dan Maret.

Kelompok volatile food tercatat deflasi pada triwulan I 2015, terutama bersumber dari meningkatnya pasokan beberapa komoditas pangan. Kelompok volatile food tercatat deflasi 


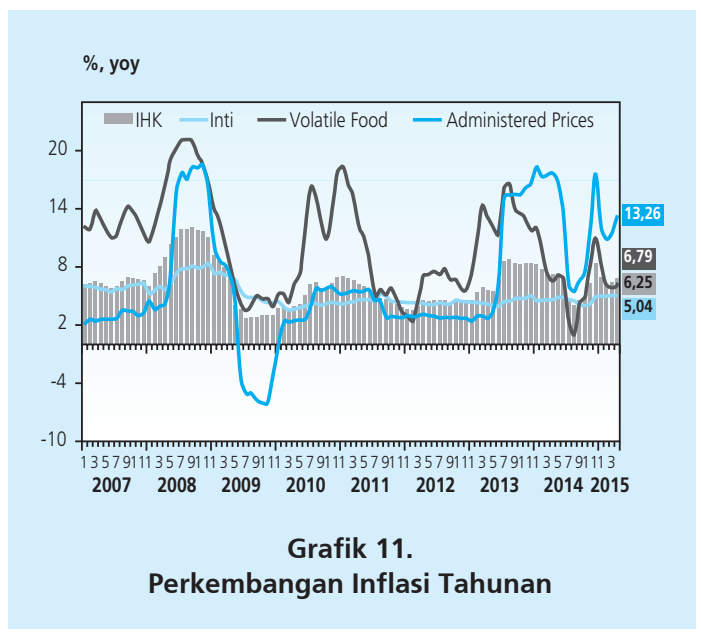

sebesar -1,98\% (qtq) atau 5,87\% (yoy). Deflasi kelompok volatile food didukung oleh tingginya pasokan aneka cabai sejalan dengan berlangsungnya panen raya di sejumlah daerah sentra. Selain aneka cabai, melimpahnya pasokan pada komoditas daging ayam dan telur ayam juga menyumbang penurunan inflasi volatile food.

Pada triwulan I 2015, kelompok administered prices mengalami deflasi terutama didorong oleh koreksi harga BBM serta dampak lanjutannya terhadap angkutan dalam kota. Kelompok administered prices tercatat deflasi sebesar $-3,91 \%$ (qtq) atau 11,49\% (yoy). Koreksi harga BBM terjadi pada Januari, yaitu pada tanggal 1 Januari 2015 harga bensin turun dari Rp8.500 per liter menjadi Rp7.600 per liter dan solar turun dari Rp7.500 per liter menjadi Rp7.250 per liter. Selanjutnya, pada tanggal 14 Januari 2015 harga bensin kembali turun dari Rp7.600 per liter menjadi Rp6.600 per liter dan harga solar turun dari Rp7.250 per liter menjadi Rp6.400 per liter.

Tekanan inflasi inti terkendali pada triwulan I 2015, sejalan dengan koreksi harga komoditas global dan perlambatan ekonomi domestik. Inflasi inti tercatat sebesar 1,25\% (qtq) atau 5,04\% (yoy), sedikit lebih rendah dibandingkan triwulan sebelumnya sebesar 1,70\% (qtq). Penurunan tekanan eksternal terutama didorong oleh penurunan harga global di tengah tekanan pelemahan rupiah pada triwulan I 2015. Demikian pula dengan permintaan domestik yang tumbuh lebih rendah dari perkiraan sebelumnya.

Inflasi inti yang terkendali pada triwulan I 2015 turut didukung oleh terkendalinya ekspektasi inflasi. Consensus Forecast triwulanan periode Maret 2015 menunjukkan bahwa proyeksi inflasi IHK 2015 akhir tahun menurun dibandingkan survei periode Desember 2014. Penurunan ekspektasi tersebut diprakirakan terkait dengan beberapa kebijakan administered prices yang ditetapkan pemerintah pada awal tahun, yaitu penurunan harga bensin dan solar sebanyak 2 kali serta realisasi deflasi pangan pada awal tahun. 
Meskipun inflasi pada triwulan I 2015 secara nasional terkendali, namun beberapa daerah seperti Maluku, Kalimantan Barat, Sulawesi Utara, dan Maluku Utara mencatat inflasi yang tinggi dibandingkan rata-rata nasional. Lebih tingginya inflasi tahunan pada beberapa daerah tersebut disebabkan oleh kenaikan harga beras yang cukup tinggi karena kendala pasokan dan penyaluran raskin, serta kenaikan harga ikan karena kondisi cuaca yang tidak kondusif. Pada April 2015, tekanan inflasi yang meningkat terjadi hampir merata di seluruh daerah. Inflasi tertinggi terjadi di wilayah Sumatera, diikuti oleh Jawa. Selain penyesuaian harga administered prices, inflasi di daerah tersebut didorong oleh kenaikan tarif angkutan udara, biaya kontrak rumah, serta peningkatan tarif kereta api jarak jauh. Sementara inflasi di Kalimantan dan Sulampua-Bali-Nusra relatif lebih rendah karena terdapat provinsi yang mengalami deflasi (Gambar 2).

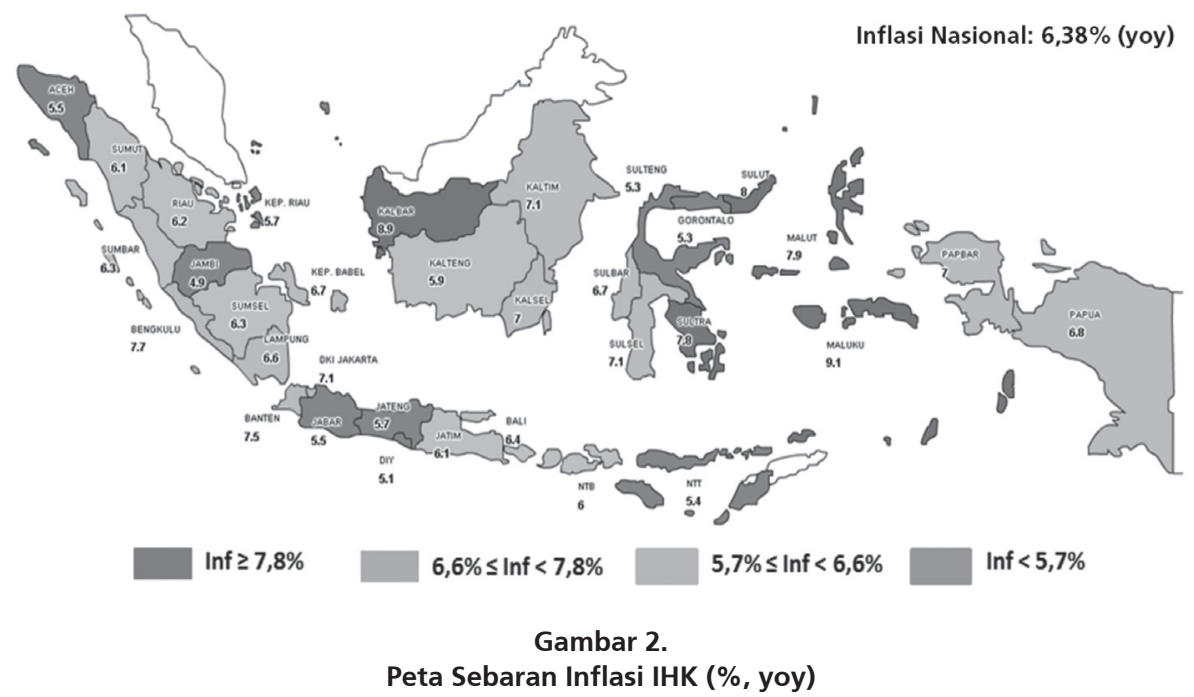

\section{PERKEMBANGAN MONETER, PERBANKAN, DAN SISTEM PEMBAYARAN}

\subsection{Moneter}

Perkembangan suku bunga dan uang beredar masih sesuai dengan arah kebijakan moneter yang ditempuh Bank Indonesia. Selama triwulan I 2015, rata-rata suku bunga PUAB meningkat sementara suku bunga kredit perbankan relatif stabil. Perkembangan tersebut memengaruhi dinamika likuiditas perekonomian, sebagaimana tercermin pada likuiditas di PUAB dan perbankan yang terjaga.

Kondisi Pasar Uang Antar Bank (PUAB) pada triwulan I 2015 ditandai oleh likuiditas yang tetap terjaga. Rata-rata suku bunga PUAB O/N mengalami sedikit peningkatan dari 5,81\% pada triwulan IV 2014 menjadi 5,84\% pada triwulan I 2015 (Grafik 12). Suku bunga PUAB O/N sempat meningkat seiring langkah antisipatif perbankan dalam menjaga kecukupan likuiditas 
terkait kondisi di sistem pembayaran. Rata-rata posisi DF pada triwulan I turun dari Rp141,05 triliun menjadi Rp113,25 triliun. Namun, kondisi likuiditas secara industri masih likuid yang terlihat dari masih tingginya likuiditas overnight yang di tempatkan di DF. Rata-rata spread suku bunga max-min di PUAB menurun dari 94 bps pada triwulan IV 2014 menjadi 27 bps triwulan I 2015 (Grafik 13). Secara nominal, volume rata-rata PUAB total pada triwulan I 2015 tercatat naik menjadi Rp11,00 triliun dari Rp10,44 triliun pada triwulan sebelumnya. Kenaikan volume PUAB total lebih dikontribusi oleh kenaikan volume PUAB O/N yang naik dari Rp 6,37 triliun menjadi Rp6,78 triliun.

Suku bunga deposito perbankan menurun, sementara suku bunga kredit sedikit meningkat. Suku bunga Rata-rata Tertimbang (RRT) deposito pada triwulan I 2015 masih melanjutkan tren penurunan dari triwulan sebelumnya. Kondisi tersebut didorong oleh penurunan BI Rate pada Februari 2015, serta semakin longgarnya likuiditas perbankan seiring tingginya pertumbuhan DPK di atas pertumbuhan kredit yang melambat. RRT suku bunga deposito turun dari $8,78 \%$ menjadi 8,62\% yang disumbang oleh penurunan suku bunga deposito pada hampir semua tenor, kecuali tenor 12 bulan. Sementara itu, suku bunga RRT kredit pada triwulan I 2015 tercatat di level 12,99\% atau meningkat dibandingkan dengan triwulan sebelumnya yakni sebesar 12,95\%. Kenaikan suku bunga RRT kredit terutama disumbang oleh kenaikan suku bunga Kredit Konsumsi (KK), dari 13,58\% menjadi 13,68\%, dan suku bunga Kredit Modal Kerja (KMK), dari 12,79\% menjadi 12,82\%. Sementara itu, suku bunga Kredit Investasi (KI) turun dari 12,36\% menjadi 12,32\%. Dengan perkembangan tersebut, spread antara suku bunga kredit dan deposito pada triwulan I 2015 meningkat menjadi 437 bps dari 417 bps.

Likuiditas perekonomian (M2) pada triwulan I 2015 mengalami peningkatan didorong oleh peningkatan uang kuasi dan M1 (Giro). Pertumbuhan M2 pada triwulan I 2015 meningkat

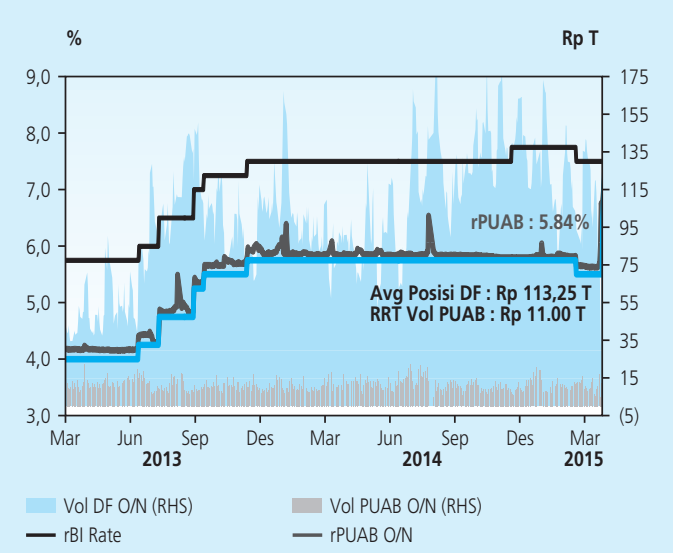

Grafik 12. aKoridor Suku Bunga Operasional Moneter

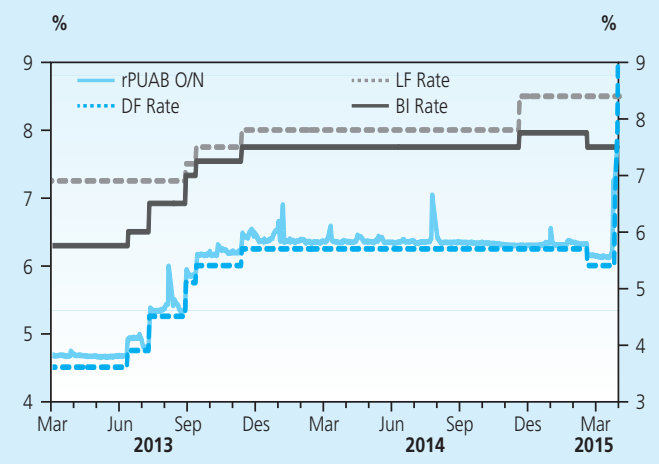

Grafik 13.

BI Rate, DF Rate dan suku bunga PUAB ON 
menjadi 16,26\% (yoy) dari 11,88\% (yoy) pada triwulan sebelumnya. Berdasarkan komponennya, peningkatan M2 bersumber dari kenaikan pertumbuhan uang kuasi, dari 13,80\% (yoy) pada triwulan IV 2014 menjadi 17,60\% (yoy) pada triwulan I 2015, dan kenaikan pertumbuhan M1, dari 6,22\% (yoy) pada triwulan IV 2014 menjadi 12,19\% (yoy) pada triwulan I 2015. Peningkatan $\mathrm{M} 1$ tersebut didorong oleh peningkatan simpanan giro rupiah yang tumbuh dari 7,28\% (yoy) pada triwulan IV 2014 menjadi 20,90\% (yoy) pada triwulan I 2015. Sementara, komponen M1 lainnya yaitu uang kartal terus mengalami perlambatan pada triwulan I 2015 menjadi 1,2\% (yoy) dari 4,9\% (yoy) pada triwulan sebelumnya, sejalan dengan perlambatan pertumbuhan ekonomi.

Berdasarkan faktor yang mempengaruhi, kenaikan M2 terutama bersumber dari peningkatan tagihan bersih kepada pemerintah pusat (NCG). Pada triwulan I 2015, NCG tumbuh dari 2,5\% (yoy) menjadi 38,2\% (yoy) sejalan dengan operasi keuangan pemerintah. Sementara itu, pertumbuhan aktiva luar negeri bersih (NFA) mengalami peningkatan dari 9,34\% (yoy) pada triwulan IV 2014 menjadi 20,93\% (yoy) pada triwulan I 2015.

\subsection{Industri Perbankan}

Stabilitas sistem keuangan tetap solid ditopang oleh ketahanan sistem perbankan dan relatif terjaganya kinerja pasar keuangan. Ketahanan industri perbankan tetap kuat dengan risiko kredit, likuiditas dan pasar yang cukup terjaga, serta dukungan modal yang kuat.

Laju pertumbuhan kredit pada triwulan I 2015 melambat seiring dengan perlambatan ekonomi. Pertumbuhan kredit ${ }^{2}$ pada triwulan 12015 masih rendah yaitu tercatat 11,3\% (yoy), menurun dari triwulan sebelumnya sebesar 11,6\% (yoy) (Grafik 14). Perlambatan laju kredit terutama disumbang oleh KMK yang tumbuh melambat dari 10,8\% (yoy) pada triwulan IV 2014 menjadi 9,9\% (yoy) pada triwulan I 2015. Sementara itu, pertumbuhan KI dan KK sedikit meningkat, masing-masing menjadi 13,5\% (yoy) dan 11,6\% (yoy) pada triwulan I 2015 dari 13,1\% (yoy) dan 11,5 \%(yoy) pada triwulan IV 2014. Secara sektoral, perlambatan pertumbuhan kredit antara lain terjadi pada sektor perdagangan, listrik gas dan air (LGA), jasa lainnya, pertanian, dan pertambangan. Penurunan kredit di sektor perdagangan, transportasi dan LGA lebih disebabkan faktor melambatnya pertumbuhan ekonomi.

2 Perhitungan pertumbuhan penyaluran kredit sebesar 11,3\% (yoy) pada triwulan I 2015 menggunakan konsep perbankan, yaitu pinjaman rupiah dan valas yang diberikan oleh Bank Umum (termasuk kantor cabang yang beroperasi di luar wilayah Indonesia) kepada penduduk (termasuk Pemerintah Pusat) dan bukan penduduk. Sementara itu, pertumbuhan kredit menggunakan konsep moneter pada triwulan I 2015 tercatat sebesar 11,1\% (yoy). Kredit menurut konsep moneter adalah pinjaman rupiah dan valas yang diberikan oleh Bank Umum dan BPR (tidak termasuk kantor cabang bank yang beroperasi di luar wilayah Indonesia) kepada penduduk (tidak termasuk Pemerintah Pusat). 
Pertumbuhan Dana Pihak Ketiga (DPK) pada triwulan I 2015 meningkat cukup tinggi. Pertumbuhan DPK ${ }^{3}$ pada triwulan I 2015 tercatat sebesar 16,0\% (yoy), meningkat dari triwulan sebelumnya sebesar 12,3\% (yoy) (Grafik 15). Pertumbuhan DPK terutama ditopang oleh pertumbuhan giro yang meningkat dari 5.1\% (yoy) pada triwulan IV 2014 menjadi 17.7\% (yoy) pada triwulan I 2015. Selain itu, kenaikan pertumbuhan deposito dari $20.9 \%$ (yoy) pada triwulan IV 2014 menjadi 23.7\% (yoy) pada triwulan I 2015 turut menopang peningkatan DPK. Namun, pertumbuhan tabungan masih menunjukkan perlambatan, dari 5.9\% (yoy) pada triwulan IV 2014 menjadi 4.0\% (yoy) pada triwulan I 2015.

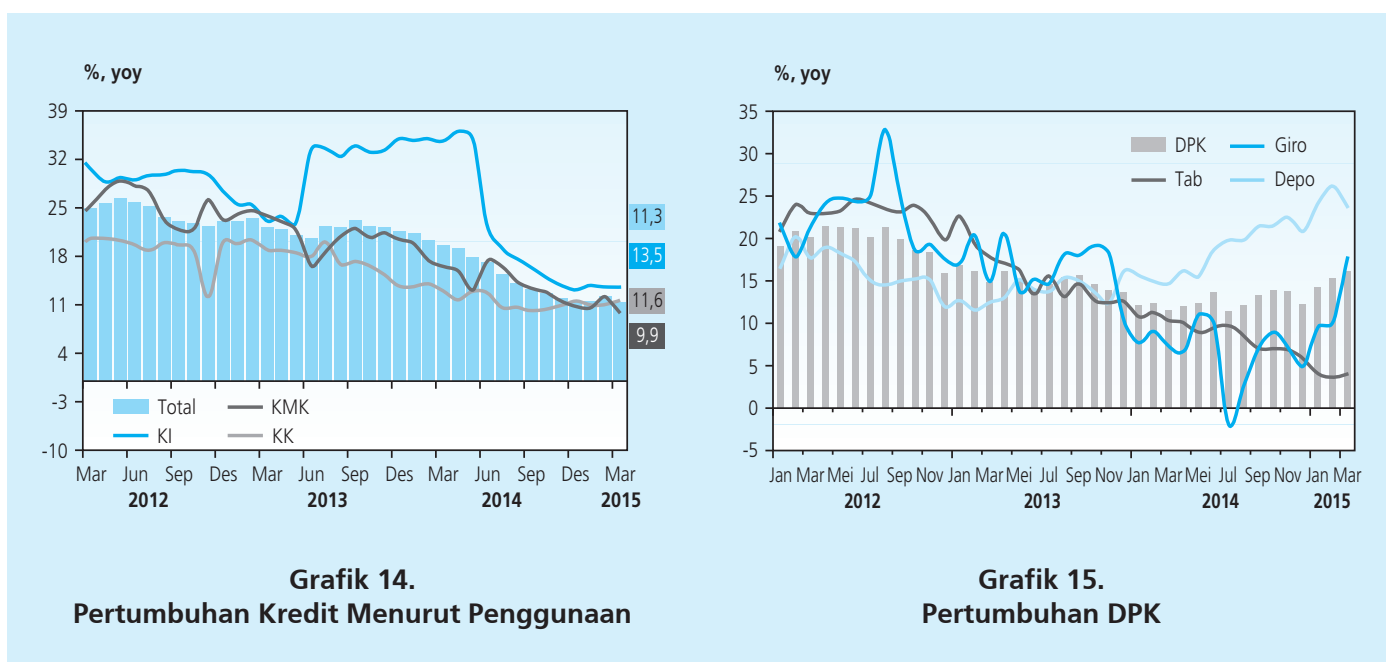

Kondisi perbankan masih cukup terjaga di tengah melambatnya pertumbuhan kredit. Pada triwulan I 2015, ketahanan permodalan masih memadai dengan rasio kecukupan modal (Capital Adequacy Ratio/CAR) yang masih tinggi sebesar 20,7\%, jauh di atas ketentuan minimum $8 \%$ (Tabel 2). Sementara itu, rasio kredit bermasalah (Non Performing Loan/NPL) tetap rendah dan stabil di kisaran 2,4\% (gross).

3 Perhitungan pertumbuhan DPK sebesar 16,0\% (yoy) menggunakan konsep perbankan. DPK menurut konsep perbankan adalah simpanan milik pihak ketiga, baik dalam rupiah maupun valas pada Bank Umum (termasuk kantor cabang bank yang beroperasi di luar wilayah Indonesia) dalam bentuk tabungan, giro dan simpanan berjangka. DPK menurut konsep perbankan meliputi pula simpanan milik Pemerintah Pusat dan simpanan milik bukan penduduk. Sementara itu, DPK menueut konsep moneter pada triwulan 12015 mencatat pertumbuhan sebesar 16,3\% (yoy), lebih tinggi dari triwulan sebelumnya sebesar 12,0\% (yoy). DPK menurut konsep moneter adalah simpanan milik pihak ketiga, baik dalam rupiah maupun valas pada Bank Umum dan BPR (tidak termasuk kantor cabang bank yang beroperasi di wilayah Indonesia) dalam bentuk tabungan, giro, dan simpanan berjangka. DPK menurut konsep moneter tidak termasuk simpanan milik Pemerintah Pusat dan simpanan milik bukan penduduk. 


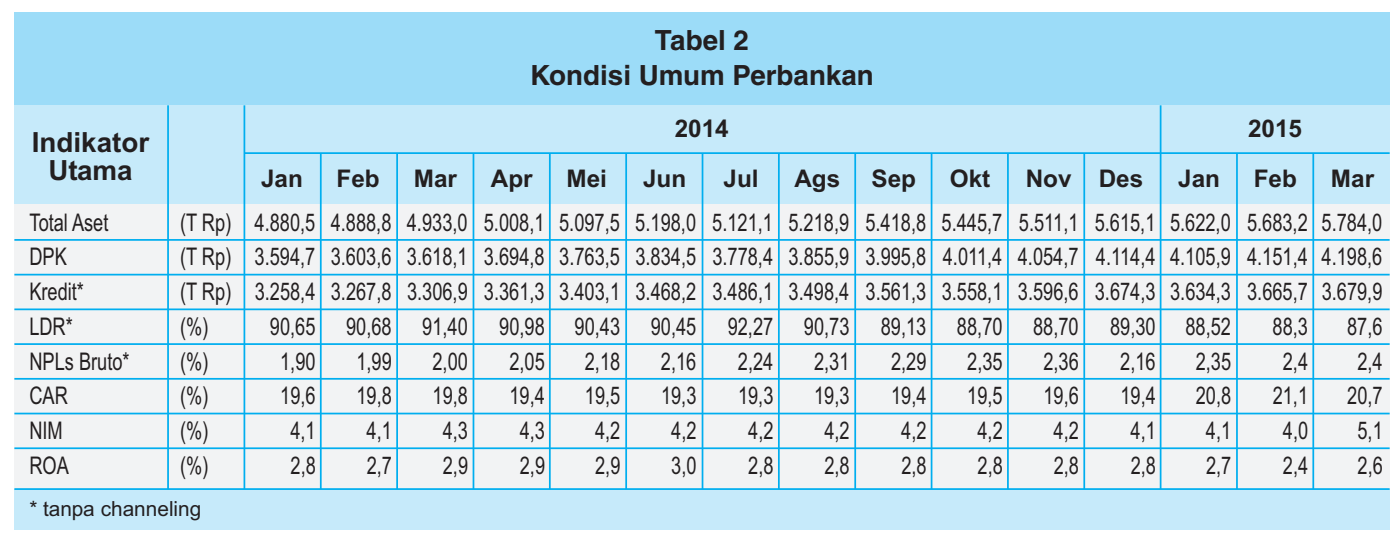

\subsection{Pasar Saham dan Pasar Surat Berharga Negara}

Perkembangan pasar saham domestik selama triwulan I 2015 menunjukkan kinerja positif, didorong oleh sentimen positif domestik seiring rilis data fundamental ekonomi yang membaik. Kinerja IHSG triwulan I 2015 mencapai level 5.518,68 (31 Mar 2015), naik sebesar 292 poin atau 5,58\% (qtq) (Grafik 16). IHSG beberapa kali mencatatkan rekor tinggi sepanjang waktu selama periode Januari hingga Maret 2015. Penguatan ini dipengaruhi oleh sentimen positif domestik atas rilis data beberapa indikator fundamental ekonomi Indonesia yang lebih baik dari perkiraan serta sentimen positif rilis laporan keuangan dan pembayaran dividen emiten di bulan Maret. Meskipun demikian, tekanan terhadap nilai tukar membuat penguatan IHSG relatif tertahan. Sementara di sisi global, sentimen positif muncul dari kesepakatan Eurogroup terkait masalah utang Yunani serta rilis FOMC yang cenderung dovish turut membawa pergerakan positif di pasar saham domestik. Kinerja IHSG tergolong baik dibandingkan dengan pergerakan bursa saham kawasan (Vietnam, Filipina, Thailand, Malaysia dan Singapura). Pertumbuhan IHSG termasuk besar di antara negara kawasan dan berada di bawah Filipina (9,8\%), namun masih berada di atas Malaysia, Singapura, dan Vietnam.

Perkembangan pasar SBN menunjukkan kinerja yang positif, didorong oleh sentimen positif domestik. Sentimen positif tersebut berasal dari rilis beberapa indikator ekonomi Indonesia yang lebih baik dari prakiraan sebelumnya. Membaiknya kondisi pasar SBN ditandai oleh yield SBN yang turun di seluruh tenor (Grafik 17). Secara keseluruhan, yield turun sebesar 38 bps menjadi 7,42\% pada triwulan I 2015 dari 7,80\% pada triwulan IV 2014. Adapun yield jangka pendek, menengah dan panjang masing-masing turun sebesar 37 bps, 33 bps dan 51 bps menjadi 7,04\%,7,45\% dan 7,85\% pada triwulan I 2015. Sementara, yield benchmark 10 tahun turun sebesar 36 bps dari 7,80\% pada triwulan IV 2014 menjadi 7,44\% pada triwulan I 2015. Penurunan yield tersebut didorong oleh penurunan BI Rate pada Februari 2015. Selain itu, minat investor terhadap SBN masih tinggi, tercermin dari lelang SBN pemerintah yang masih mengalami oversubscribed. Di tengah penurunan yield SBN yang terjadi, investor nonresiden mencatatkan net beli sebesar Rp42,73 triliun pada triwulan I 2015, meningkat dibandingkan 
triwulan sebelumnya yang sebesar Rp13,99 triliun. Meskipun demikian, pasar SBN sempat mengalami tekanan pada bulan Maret, didorong oleh adanya tekanan terhadap nilai tukar rupiah dan kembali meningkatnya ekspektasi kenaikan FFR seiring dengan membaiknya rilis data ekonomi AS.

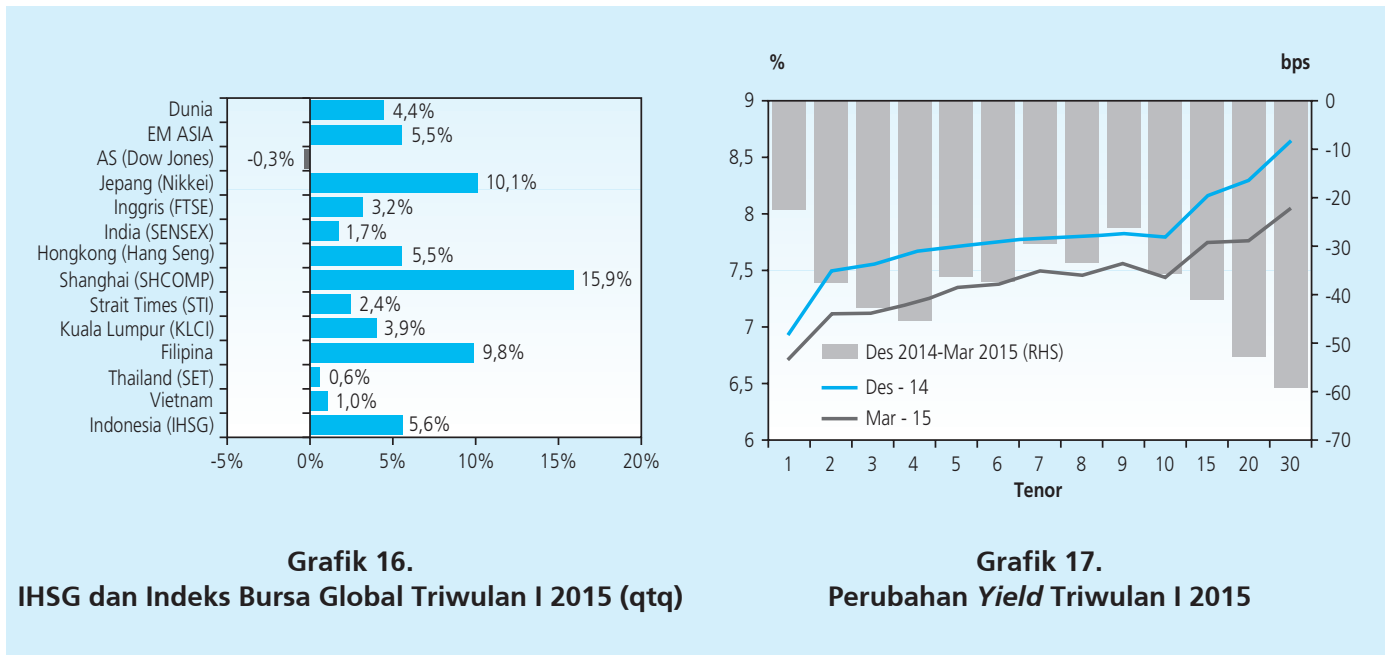

\subsection{Pembiayaan Non Bank}

Pembiayaan ekonomi nonbank pada triwulan I 2015 menurun. Total pembiayaan melalui penerbitan saham perdana, right issue, obligasi korporasi, medium term notes, promissory notes dan lembaga keuangan lainnya tercatat sebesar Rp22,2triliun atau lebih kecil dibandingkan dengan triwulan sebelumnya yang mencapai Rp44,6 triliun. Pembiayaan terbesar masih bersumber dari penerbitan obligasi yaitu sebesar Rp12,8 triliun. Turunnya pembiayan ekonomi nonbank terjadi seiring dengan tren naiknya tingkat yield Surat Utang Negara (SUN) sehingga meningkatkan cost of fund penerbitan obligasi bagi investor maupun korporasi. Selain itu, rencana kenaikan FFR yang kembali meningkat seiring dengan perbaikan data ekonomi AS pada awal tahun 2015 turut mendorong investor untuk cenderung wait and see dan menunda rencana emisinya.

\subsection{Perkembangan Sistem Pembayaran}

Secara umum, perkembangan sistem pembayaran di kelompok tunai sejalan dengan perkembangan ekonomi domestik. Rata-rata harian Uang Kartal yang Diedarkan (UYD) pada triwulan I 2015 adalah sebesar Rp462,6 triliun atau tumbuh sebesar 3,2\% (yoy), menurun dibandingkan pertumbuhan triwulan sebelumnya sebesar 13,6\% (yoy). Hal ini sejalan dengan melambatnya pertumbuhan ekonomi Indonesia pada triwulan I 2015. Selain itu, pertumbuhan 
UYD secara triwulanan mengalami penurunan sebesar -12,5\% (qtq) karena faktor siklikal adanya arus balik dana perbankan dan masyarakat ke Bank Indonesia, pasca tingginya kebutuhan uang kartal pada periode Natal dan liburan akhir tahun 2014.

Di tengah tren pertumbuhan UYD yang dipengaruhi faktor siklikal tersebut, Bank Indonesia terus berupaya meningkatkan kelayakan uang yang beredar. Selama triwulan I 2015, sejumlah 1,54 miliar lembar/keping Uang Tidak Layak Edar (UTLE) senilai Rp40,9 triliun telah dimusnahkan dan diganti dengan uang rupiah yang layak edar. Jumlah pemusnahan UTLE tersebut lebih tinggi dibandingkan dengan triwulan IV 2014 yang tercatat sebesar 1,50 miliar lembar/keping atau senilai Rp30,7 triliun. Meningkatnya pemusnahan UTLE tersebut disebabkan oleh tingginya aliran uang rupiah masuk (inflow) ke Bank Indonesia, serta meningkatnya jumlah kandungan UTLE yang disetorkan perbankan.

Transaksi sistem pembayaran tetap dapat berjalan secara aman dan lancar selama triwulan I 2015. Pada triwulan I 2015 transaksi sistem pembayaran nontunai mengalami penurunan baik dari sisi nilai maupun volume transaksi apabila dibandingkan dengan triwulan sebelumnya. Penurunan nilai transaksi tercatat sebesar Rp6.121,1 triliun atau menurun sebesar 13,4\% (qtq) sedangkan penurunan volume transaksi tercatat sebesar 4,3 juta transaksi atau 0,3\% (qtq) (Tabel 3). Secara umum, penurunan nilai transaksi terjadi pada seluruh kelompok transaksi terutama transaksi Operasi Moneter yang turun sebesar Rp4.187,5 triliun atau turun 22,0\% dibandingkan dengan periode triwulan sebelumnya. Di sisi lain, penurunan volume transaksi terutama disebabkan oleh menurunnya transaksi masyarakat melalui instrumen nontunai khususnya yang diselenggarakan oleh industri. Penurunan volume transaksi terbesar terjadi pada transaksi Alat Pembayaran dengan Menggunakan Kartu (APMK) yang menurun sebesar 11,8 juta transaksi atau 1,0\% (qtq).

\begin{tabular}{|c|c|c|c|c|c|c|}
\hline \multicolumn{7}{|c|}{$\begin{array}{c}\text { Tabel } 3 \\
\text { Perkembangan Nilai Sistem Pembayaran NonTunai }\end{array}$} \\
\hline \multirow{3}{*}{ Transaksi Sistem Pembayaran Non Tunai } & & & & & \multirow{3}{*}{ Q-I } & \multirow{3}{*}{$\begin{array}{c}\text { Nilai (triliun Rp) } \\
\text { \% naik/(turun) } \\
\text { QtQ (IV to I) }\end{array}$} \\
\hline & \multicolumn{4}{|c|}{2014} & & \\
\hline & Q-I & Q-II & Q-III & Q-IV & & \\
\hline BI-RTGS & $23.817,8$ & $24.150,4$ & $29.872,4$ & $33.041,6$ & $28.879,2$ & $-12,6 \%$ \\
\hline BI-SSSS & $7.173,6$ & $6.396,9$ & $9.366,8$ & $10.636,7$ & $8.758,3$ & $-17,7 \%$ \\
\hline Kliring & 667,8 & 710,7 & 716,4 & 770,9 & 732,5 & $-5,0 \%$ \\
\hline Debet & 399,1 & 417,9 & 411,9 & 432,3 & 395,4 & $-8,6 \%$ \\
\hline Kredit & 268,7 & 292,8 & 304,5 & 338,6 & 337,1 & $-0,4 \%$ \\
\hline APMK & $1.077,3$ & $1.158,5$ & $1.215,5$ & $1.248,8$ & $1.207,0$ & $-3,3 \%$ \\
\hline Kartu Kredit & 56,9 & 63,6 & 65,1 & 69,4 & 66,0 & $-4,9 \%$ \\
\hline Kartu ATM dan ATM/Debet & $1.020,5$ & $1.094,9$ & $1.150,4$ & $1.179,3$ & $1.141,0$ & $-3,2 \%$ \\
\hline Uang Elektronik & 0,7 & 0,8 & 0,9 & 0,8 & 0,8 & $5,4 \%$ \\
\hline Total & $32.737,2$ & $32.417,4$ & $41.172,0$ & $45.698,9$ & $39.577,8$ & $-13,4 \%$ \\
\hline
\end{tabular}


Sejalan dengan penurunan nilai dan volume transaksi sistem pembayaran nontunai pada triwulan I 2015, transaksi pembayaran yang diselesaikan melalui Sistem BI-RTGS juga mengalami penurunan baik dari sisi nilai maupun volume. Ketersediaan sistem BI-RTGS sebagai setelmen dana, BI-SSSS sebagai setelmen surat berharga pemerintah dan Bank Indonesia, serta SKNBI yang mencapai $100 \%$ serta tidak adanya gangguan yang signifikan dalam penyelenggaraan APMK dan Uang Elektronik pada triwulan I 2015. Nilai transaksi pembayaran yang diselesaikan melalui Sistem BI-RTGS turun sebesar Rp4.162,5 triliun (turun sebesar 12,6\%,qtq) menjadi Rp28.879,2 triliun. Penurunan nilai transaksi tersebut terutama disebabkan oleh Operasi Moneter yang memiliki kontribusi sebesar 51,4\% dari keseluruhan transaksi melalui Sistem BIRTGS. Semenatar itu, volume transaksi pembayaran yang diselesaikan melalui Sistem BI-RTGS menurun sebesar 1,8 juta transaksi atau turun 38,5\% (qtq) dibandingkan dengan triwulan sebelumnya. Dari sisi persentase, penurunan volume transaksi Bank Indonesia Real Time Gross Settlement (BI-RTGS) mencatat penurunan tertinggi, yaitu sebesar 38,5\% (turun sebesar 1.8 juta transaksi dibandingkan dengan triwulan sebelumnya). Penurunan volume transaksi disebabkan oleh adanya kebijakan capping RTGS4.

\section{PROSPEK PEREKONOMIAN}

Bank Indonesia memperkirakan pertumbuhan ekonomi akan membaik, terutama pada semester II 2015. Pertumbuhan yang membaik ini didukung oleh meningkatnya konsumsi dan investasi sejalan dengan meningkatnya realisasi pengeluaran fiskal oleh pemerintah serta meningkatnya penyaluran kredit oleh perbankan. Percepatan realisasi belanja Pemerintah baik di kementrian/lembaga maupun untuk implementasi proyek-proyek infrastruktur menjadi kunci dalam mendorong pertumbuhan ekonomi 2015.

Inflasi pada tahun 2015 diprakirakan akan lebih rendah dibandingkan tahun sebelumnya dan berada dalam rentang sasaran inflasi sebesar $4 \pm 1 \%$. Di sisi domestik, tekanan inflasi dari sisi permintaan diprakirakan relatif moderat sejalan dengan pertumbuhan ekonomi yang di bawah tingkat potensialnya dan masih rendahnya utilisasi kapasitas produksi. Ekspektasi inflasi diperkirakan juga tetap terjaga dengan dukungan kebijakan dan koordinasi yang baik antara Bank Indonesia dan Pemerintah. Tekanan inflasi dari sisi eksternal diprakirakan tidak terlalu besar. Hal tersebut didukung oleh perkiraan terbatasnya peningkatan harga-harga komoditas internasional sejalan dengan laju perbaikan perekonomian dunia yang berlangsung secara gradual dan nilai tukar yang relatif stabil.

Bank Indonesia akan terus mencermati beberapa risiko perekonomian yang berasal dari eksternal maupun domestik. Dari sisi global, risiko muncul dari PDB dunia yang berpotensi

4 Kebijakan capping (berdasarkan SE BI No.16/18/DPSP) yang diberlakukan mulai tanggal 15 Desember 2014, dimana transaksi transfer kredit antar Bank untuk kepentingan nasabah dengan nominal sampai dengan Rp100.000.000,00 harus dilaksanakan melalui SKNBI. 
tumbuh lebih rendah dari perkiraan yang khususnya disebabkan oleh pertumbuhan ekonomi AS yang tidak setinggi perkiraan. Selain itu, PDB dunia juga berpotensi tumbuh lebih rendah dari perkiraan apabila perekonomian Tiongkok mengalami perlambatan yang lebih dalam. Risiko global juga muncul dari kemungkinan harga komoditas internasional yang turun lebih jauh dari perkiraan. Dari sisi pasar keuangan global, risiko yang perlu diwaspadai adalah ketidakpastian waktu dan besarnya kenaikan suku bunga Fed Fund Rate (FFR) di AS. Di sisi domestik, belanja pemerintah perlu dicermati karena menentukan implementasi proyek-proyek infrastruktur yang berperan penting dalam menjaga optimisme terhadap prospek perekonomian. 